\title{
Staphylococcal secretory inhibitor of platelet microbicidal protein is associated with prostatitis source
}

Correspondence

luri B. Ivanov

mil-for@rambler.ru

Received 1 June 2006

Accepted 16 August 2006 luri B. Ivanov, Viktor A. Gritsenko and Michael D. Kuzmin

Department of Human Microbiology, Institute of Cellular and Intracellular Symbiosis, Russian Academy of Sciences, Orenburg, Russia

\begin{abstract}
This study reports the detection of an extracellular staphylococcal product, designated secretory inhibitor of platelet microbicidal protein (SIPMP), that causes local inhibition of the bactericidal action of platelet microbicidal protein (PMP) in the fluid phase. Urethral isolates of Staphylococcus aureus $(n=24)$ and coagulase-negative staphylococci (CNS) $(n=47)$ from patients with or without chronic bacterial prostatitis (CBP) were tested. SIPMP production was tested by inhibition of PMP bioactivity against Bacillus subtilis and was expressed as percentage inhibition of PMP bactericidal activity. The PMP susceptibility of staphylococcal strains was determined by exposing bacterial cells to serial dilutions of PMP. Staphylococci from patients without CBP produced SIPMP at levels of $10 \cdot 3 \pm 1 \cdot 2$ and $13 \cdot 25 \pm 1 \cdot 72 \%$ for $S$. aureus and CNS, respectively. Strains isolated from men with CBP inhibited PMP-induced killing of $B$. subtilis by $23 \cdot 38 \pm 4 \cdot 2 \%$ $(P<0.05)$ and $23.69 \pm 1.87 \%(P<0.01)$ for $S$. aureus and CNS, respectively. SIPMP production correlated with staphylococcal resistance to PMP $\left(r^{2}=0.6082\right.$ and 0.7264 for $S$. aureus and CNS, respectively). SIPMP represents a hitherto unrecognized determinant of staphylococcal pathogenicity. These results suggest that SIPMP production is associated with the CBP source. Data from this study may have significant implications for the understanding of the pathogenesis of CBP.
\end{abstract}

\section{INTRODUCTION}

A number of micro-organisms are able to infect the reproductive tract tissues in humans with serious consequences for reproductive function (Domingue \& Hellstrom, 1998; Everaert et al., 2003). A common result of microbial infection of the reproductive tract is prostatitis, a condition that may lead to transient or permanent infertility (Schoor, 2002; Everaert et al., 2003). Bacterial infection of the prostate may occur as a result of ascending urethral infection or by reflux of infected urine into prostatic ducts emptying into the posterior urethra (Terai et al., 2000). Other possible routes of prostatitis include invasion of bacteria by lymphogenous or haematogenous spread (Domingue \& Hellstrom, 1998). Chronic bacterial prostatitis (CBP) is a subtle illness, characterized by the persistence of bacteria in the prostatic secretory system (Schoor, 2002; Everaert et al., 2003). The most common causative agents of CBP are coagulase-negative staphylococci (CNS) and Staphylococcus aureus (Lowentritt et al., 1995; Domingue \& Hellstrom, 1998; Ivanov, 2005). As it is difficult to establish precisely the significance of various

Abbreviations: $\mathrm{CBP}$, chronic bacterial prostatitis; CNS, coagulasenegative staphylococci; PMP, platelet microbicidal protein; SIPMP, secretory inhibitor of platelet microbicidal protein. micro-organisms in the pathogenesis of CBP, it is imperative to delineate both microbial and host factors that contribute to its development (Domingue \& Hellstrom, 1998; Schoor, 2002; Hua et al., 2005).

The major role of endogenous cationic antimicrobial peptides in preventing the onset of infection has been emphasized recently (Hancock \& Chapple, 1999; Dürr \& Peschel, 2002). Such peptides have also been found by several authors in human platelets and are designated $\beta$-lysins (Donaldson \& Tew, 1977), thrombocidins (Krijgsveld et al., 2000), thrombodefensins (Dankert, 1988) and platelet microbicidal protein (PMP) (Yeaman, 1997; Ivanov, 2005). These peptides are secreted at sites of infection and exert microbicidal activity against many pathogens, including Gram-positive cocci. Dankert et al. (1995) demonstrated that thrombodefensins are an important defence factor against viridans streptococcal endocarditis. Wu et al. (1994) showed that resistance in vitro of clinical staphylococcal and viridans group streptococcal strains to rabbit PMP correlated with the endovascular infectious source. The results of several studies (Dhawan et al., 1997; Kupferwasser et al., 2002) have shown that susceptibility to PMP is associated with staphylococcal endocarditis, and Kupferwasser et al. (1999) demonstrated that the staphylococcal multidrugresistance gene qacA also mediates resistance to PMP in vitro. 
In a recent publication, we showed that resistance of urethral staphylococcal and enterococcal strains to human PMP in vitro correlated with the diagnosis of CBP (Ivanov, 2005). However, it is surprising that an extracellular bacterial product demonstrating this remarkable anti-PMP potential has not been described. The purpose of this study was to define the existence of an extracellular substance, designated secretory inhibitor of PMP (SIPMP), detectable in cell-free staphylococcal culture supernatants, that displays hitherto unrecognized PMP-consuming properties. In this paper, we also report the detection in vitro of SIPMP phenotypes of urethral staphylococcal isolates, along with a comparison with isolates from patients with or without CBP.

\section{METHODS}

Preparation and standardization of PMP. PMP was prepared as described previously (Ivanov, 2005). Briefly, healthy human plateletrich plasma was obtained by low-speed centrifugation of 1 day-outdated platelets from the Blood Donor Department of the Orenburg Regional Medical Center. The platelet-rich plasma was then dispensed into polypropylene tubes and centrifuged again at $250 \mathrm{~g}$ for $30 \mathrm{~min}$ at $25^{\circ} \mathrm{C}$. The supernatants were removed and centrifuged at $1000 \mathrm{~g}$ for $30 \mathrm{~min}$ at $25^{\circ} \mathrm{C}$ and the sedimented platelets were washed three times with Tyrode's buffer $(138 \mathrm{mM} \mathrm{NaCl}, 3.6 \mathrm{mM}$ $\mathrm{KCl}, 10 \mathrm{mM} \mathrm{NaHCO} 3,0.4 \mathrm{mM} \mathrm{NaH} \mathrm{PO}_{4}, 10 \mathrm{mM} \mathrm{MgCl}_{2}, 6 \mathrm{mM}$ glucose, adjusted to $\mathrm{pH} 7 \cdot 3$ with phosphoric acid). The washed platelets were suspended in 5 vols ice-cold $30 \%$ acetic acid and stirred in melting ice for $24 \mathrm{~h}$. The resulting extract was centrifuged at $10000 \mathrm{~g}$ for $15 \mathrm{~min}$ and the PMP-rich supernatant was recovered. PMP preparations were stored at $-20^{\circ} \mathrm{C}$ and used for subsequent studies within 30 days. PMP bioactivity assays were performed with Bacillus subtilis ATCC 6633, an indicator organism highly sensitive to the bactericidal action of PMP (Donaldson \& Tew, 1977). Exposure of $10^{8}$ washed human platelets $\mathrm{ml}^{-1}$ to $5 \mathrm{ml}$ ice-cold $30 \%$ acetic acid resulted in mean supernatant protein concentrations of $\sim 70 \mathrm{mg} \mathrm{ml}^{-1}$. The PMP susceptibility of bacterial strains was determined by exposing bacterial cells to serial dilutions of PMP. B. subtilis was grown in tryptic soy broth (TSB) at $37^{\circ} \mathrm{C}$ for $18 \mathrm{~h}$; organisms were harvested by centrifugation, washed twice in PBS $(\mathrm{pH} 7 \cdot 2)$ and resuspended in PBS prior to use. Bacteria were diluted to $10^{4}$ c.f.u. $\mathrm{ml}^{-1}$ in PBS. Serial dilutions of PMP were prepared in PBS and $900 \mu \mathrm{l}$ PMP aliquots were transferred to low-protein-binding protein microtitre tubes (Costar Glass Works). To each of the tubes, $100 \mu \mathrm{l}$ bacterial suspension was added. The tubes were incubated on a rotary shaker (300 r.p.m.) at $37^{\circ} \mathrm{C}$. After $1 \mathrm{~h}$, aliquots of $200 \mu \mathrm{l}$ were plated on blood agar plates. The microbicidal activity of PMP was assessed the next day after counting colonies on the agar plates and defined as the concentration of protein that retained $\geqslant 50 \%$ lethality for B. subtilis (Hirsch, 1960). The bioactivity of such PMP preparations against $B$. subtilis ranged from 0.5 to $1 \cdot 0 \mu \mathrm{g} \mathrm{ml}^{-1}$. Control samples were found to possess no anti-B. subtilis bioactivity.

Detection of PMP resistance and SIPMP production. Wellcharacterized urethral isolates of $S$. aureus $(n=24)$ and CNS (Staphylococcus epidermidis, $n=27$; Staphylococcus hominis, $n=20$ ) from patients with or without CBP were kindly provided by Serge Cherkasov (Orenburg State Medical Academy, Orenburg, Russia). The determination of patients and cases from which the isolates were initially obtained as CBP and non-CBP was made by the contributing investigator, using standard clinical parameters, prior to knowledge of an isolates SIPMP production and PMP susceptibility. The bacteria were cultured overnight in TSB and cell-free supernatants were obtained by centrifugation. Staphylococcal supernatants were sterilized by filtration through $0.45 \mu \mathrm{m}$ pore size membranes (Millipore). Each culture supernatant $(0 \cdot 6 \mathrm{ml})$ (an equal volume of TSB was loaded in the control tubes) was combined with $0.3 \mathrm{ml}$ PMP at $3.0 \mu \mathrm{g} \mathrm{ml}^{-1}$ and incubated at $37^{\circ} \mathrm{C}$. After $1 \mathrm{~h}, 100 \mu \mathrm{l} \mathrm{B}$. subtilis suspension at $10^{4}$ c.f.u. $\mathrm{ml}^{-1}$ was added to each of the tubes. The tubes were incubated on a rotary shaker (300 r.p.m.) at $37^{\circ} \mathrm{C}$. After $1 \mathrm{~h}$, aliquots of $200 \mu \mathrm{l}$ were plated on blood agar plates. Colonies were counted after overnight incubation at $37^{\circ} \mathrm{C}$ and the numbers of surviving micro-organisms were calculated. SIPMP production was expressed as the percentage inhibition of PMP bactericidal activity and calculated using the formula: percentage inhibition $=(\mathrm{No}-\mathrm{Nk} 1) /(\mathrm{Nk} 2-\mathrm{Nk} 1) \times 100$, where $\mathrm{No}$ was the number of surviving $B$. subtilis cells in the presence of staphylococcal supernatant and PMP, Nk1 was the number of surviving B. subtilis cells in the presence of PMP alone, and Nk2 was the number of surviving B. subtilis cells in TSB.

The PMP susceptibility of bacterial strains was determined by exposing $2 \times 10^{3}$ bacterial cells to serial dilutions of PMP from $5 \mu \mathrm{g} \mathrm{ml}^{-1}$ to $15 \mu \mathrm{g} \mathrm{ml}^{-1}$, as described by Yeaman et al. (1992). To define the proportion of strains considered PMP-susceptible and PMP-resistant, a survival of $\leqslant 50 \%$ of the initial inoculum at a PMP concentration of $5 \mu \mathrm{g} \mathrm{ml}^{-1}$ was considered to be a relative PMP-susceptibility breakpoint, as in the data of Wu et al. (1994).

Statistical analyses were performed using Student's $t$-test. Correlation between SIPMP production and PMP resistance was calculated as $r^{2}$ values by the Pearson correlation calculation using Microsoft Excel. Values of $P \leqslant 0.05$ and $r^{2} \geqslant 0.5$ were considered to be significant.

\section{RESULTS AND DISCUSSION}

Among the 24 S. aureus isolates studied, 13 urethral isolates were from patients with CBP, whilst 11 isolates were from patients without CBP (Table 1). Of the CBP strains tested, $10 / 13(76 \cdot 9 \%)$ were considered to be resistant to the bactericidal action of PMP compared with only $2 / 11$ of the non-CBP isolates $(18 \cdot 2 \%, P<0 \cdot 001)$. Furthermore, $3 / 13$

Table 1. PMP susceptibility and SIPMP production of urethral staphylococcus isolates

\begin{tabular}{|lccccc|}
\hline \multirow{2}{*}{ Organism } & \multicolumn{2}{c}{ No. of PMP-resistant strains/total } & & \multicolumn{2}{c|}{ No. of SIPMP-producing strains/total } \\
\cline { 2 - 3 } \cline { 5 - 6 } & Non-CBP & CBP & & Non-CBP & CBP \\
\hline S. aureus & $2 / 11$ & $10 / 13^{*}$ & & $3 / 11$ & $8 / 13^{*}$ \\
CNS & $1 / 18$ & $27 / 29^{*}$ & & $3 / 18$ & $23 / 29^{*}$ \\
\hline
\end{tabular}

${ }^{\star} P<0 \cdot 01$. 
Table 2. PMP susceptibility of non-CBP and CBP isolates

\begin{tabular}{|c|c|c|c|}
\hline \multirow[t]{2}{*}{$\begin{array}{l}\text { No. of organisms } \\
\text { (non-CBP/CBP) }\end{array}$} & \multicolumn{3}{|c|}{$\begin{array}{l}\text { No. of PMP-resistant strains (non-CBP/CBP) } \\
\text { with different concentrations of PMP }\left(\mu \mathrm{g} \mathrm{ml}^{-1}\right)\end{array}$} \\
\hline & $\leqslant 5$ & 10 & $\geqslant 15$ \\
\hline S. aureus $(11 / 13)$ & $9 / 3$ & $1 / 7$ & $1 / 3$ \\
\hline CNS $(18 / 29)$ & $17 / 2$ & $1 / 11$ & $0 / 16$ \\
\hline
\end{tabular}

$(23 \cdot 1 \%)$ of CBP strains were resistant to $\geqslant 15 \mu \mathrm{g} \mathrm{PMP} \mathrm{ml} \mathrm{m}^{-1}$ (Table 2).

Of the 47 urethral CNS isolates tested, 29 and 18 were from CBP and non-CBP cases, respectively. A significantly higher proportion of CBP strains of CNS $(93 \cdot 1$ vs $5 \cdot 6 \%)$ was resistant to PMP compared with non-CBP strains (Table 1; $P<0 \cdot 001)$. Moreover, all non-CBP strains exhibited either low-level resistance or susceptibility to $10 \mu \mathrm{g} \mathrm{PMP} \mathrm{ml}^{-1}$. However, 16/29 CBP strains $(55 \cdot 2 \%)$ were resistant to higher bactericidal concentrations of $\mathrm{PMP}\left(\geqslant 15 \mu \mathrm{g} \mathrm{ml}^{-1}\right)$.

Among the SIPMP-producing strains, organisms isolated from patients without CBP had mean SIPMP production levels of $10 \cdot 3 \pm 1 \cdot 2$ and $13 \cdot 25 \pm 1 \cdot 72 \%$ for $S$. aureus and CNS, respectively (Table 3 ). In contrast to bacteria isolated from the control group, strains isolated from men with CBP demonstrated more intensive inhibition of the bactericidal activity of PMP. The culture supernatants of $S$. aureus from the CBP group were significantly more active in decreasing levels of PMP-induced killing of B. subtilis $(23 \cdot 38 \pm 4 \cdot 2 \%$, $P<0 \cdot 05)$. CBP strains of CNS demonstrated SIPMP production at a mean level of $23 \cdot 69 \pm 1 \cdot 87 \%(P<0 \cdot 01)$. SIPMP production correlated with staphylococcal resistance to PMP $\left(r^{2}=0.6082\right.$ and 0.7264 for $S$. aureus and CNS, respectively).

At local sites of microbial infection, platelets, neutrophils and macrophages release large amounts of different bactericidal peptides (Dürr \& Peschel, 2002). CBP is characterized by recurrent urinary tract infections and persistence of bacteria in the prostatic secretory system, despite the presence of multiple antibacterial peptides in prostatic fluid (Fair \& Parrish, 1981; Com et al., 2003). There is an urgent need to understand the virulence properties of bacteria that are associated with chronic infection of the prostate. Identifying such factor(s) would be helpful in devising effective treatment strategies.
In the present work, we detected an extracellular staphylococcal product with remarkable anti-PMP potential, which, to our knowledge, has not been described before. We anticipate that this substance represents a novel determinant of staphylococcal pathogenicity, as it probably causes local inhibition of the bactericidal action of PMP. As PMP may play an important role in the killing of staphylococci and preventing the onset of bacterial infection of the prostate, we speculated that SIPMP might enhance the infectivity of these bacteria through the abortive consumption of PMP in the fluid phase. The strategy underlying this process would be straightforward and effective. We believe that SIPMP represents a widespread and hitherto unrecognized determinant of bacterial pathogenicity. Similarly, in a study of the distribution of streptococcal inhibitor of complement variants in pharyngitis and invasive isolates by Hoe et al. (2001), $62 \%$ of group A streptococci from patients with pharyngitis produced this extracellular protein. In addition, a recent study by Fernie-King et al. (2002) showed that purified secretory inhibitor of complement could block two additional components of the immune system: lysozyme and secretory leukocyte proteinase inhibitor. Collectively, our study and the results of several other studies (Bukharin et al., 1996; Fernie-King et al., 2002; Deckers et al., 2004; Langley et al., 2005) suggest that inactivation of components of innate immunity may be important for bacterial pathogens to induce and perpetuate chronic infections of different localization by surviving or avoiding microbicidal protein-mediated clearance.

Data from the present study may have significant implications for the understanding of the pathogenesis of CBP, as well as for future improvements in the prevention and therapy of CBP. Whether or not SIPMP is truly important in pathogenicity may become evident in the future from in vivo studies with selected SIPMP-positive and SIPMP-negative strains.

Table 3. SIPMP production of urethral staphylococcus isolates

\begin{tabular}{|lrccc|}
\hline $\begin{array}{l}\text { No. of organisms } \\
\text { (non-CBP/CBP) }\end{array}$ & \multicolumn{4}{c|}{$\begin{array}{c}\text { No. of SIPMP-producing strains (non-CBP/CBP) } \\
\text { with different levels (\%) of SIPMP }\end{array}$} \\
\cline { 2 - 4 } & $\mathbf{0}$ & $\mathbf{0 \cdot 1 - 1 0 \cdot 0}$ & $\mathbf{1 0 \cdot 1 - 2 0 \cdot 0}$ & $>\mathbf{2 0}$ \\
\hline S. aureus $(11 / 13)$ & $8 / 5$ & $1 / 1$ & $2 / 2$ & $0 / 5$ \\
CNS $(18 / 29)$ & $15 / 6$ & $1 / 3$ & $2 / 5$ & $0 / 15$ \\
\hline
\end{tabular}




\section{ACKNOWLEDGEMENTS}

This study was supported by grant 04-04-97508 from the Russian Fund of Basic Research.

\section{REFERENCES}

Bukharin, O. V., Brudastov, I. A., Gritsenko, V. A. \& Deriabin, D. G. (1996). Role of the ability of bacteria to inactivate natural antiinfective resistance factors in their resistance to blood bactericidal action (blood serum). Biull Eksp Biol Med 121, 174-176.

Com, E., Bourgeon, F., Evrard, B., Ganz, T., Colleu, D., Jégou, B. \& Pineau, C. (2003). Expression of antimicrobial defensins in the male reproductive tract of rats, mice, and humans. Biol Reprod 68, 95-104.

Dankert, J. (1988). Role of platelets in early pathogenesis of viridans group streptococcal endocarditis: a study on thrombodefensins. $\mathrm{PhD}$ thesis, University of Groningen, Groningen, The Netherlands.

Dankert, J., van der Werff, J., Zaat, S. A. J., Joldersma, W., Klein, D. \& Hess, J. (1995). Involvement of bactericidal factors from thrombinstimulated platelets in clearance of adherent viridans streptococci in experimental infective endocarditis. Infect Immun 63, 663-671.

Deckers, D., Masschalck, B., Aertsen, A., Callewaert, I., van Tiggelen, C. G. M., Atanassova, M. \& Michiels, C. W. (2004). Periplasmic lysozyme inhibitor contributes to lysozyme resistance in Escherichia coli. Cell Mol Life Sci 61, 1229-1237.

Dhawan, V. K., Yeaman, M. R., Cheung, A. L., Kim, E., Sullam, P. M. \& Bayer, A. S. (1997). Phenotypic resistance to thrombin-induced platelet microbicidal protein in vitro is correlated with enhanced virulence in experimental endocarditis due to Staphylococcus aureus. Infect Immun 65, 3293-3299.

Domingue, G. J., Sr \& Hellstrom, W. J. G. (1998). Prostatitis. Clin Microbiol Rev 11, 604-613.

Donaldson, D. M. \& Tew, J. G. (1977). $\beta$-Lysin of platelet origin. Bacteriol Rev 41, 501-513.

Dürr, M. \& Peschel, A. (2002). Chemokines meet defensins: the merging concepts of chemoattractants and antimicrobial peptides in host defense. Infect Immun 70, 6515-6517.

Everaert, K., Mahmoud, A., Depuydt, C., Maeyaert, M. \& Comhaire, F. (2003). Chronic prostatitis and male accessory gland infection - is there an impact on male infertility (diagnosis and therapy)? Andrologia 35, 325-330.

Fair, W. R. \& Parrish, R. F. (1981). Antibacterial substances in prostatic fluid. Prog Clin Biol Res 75A, 247-264.

Fernie-King, B. A., Seilly, D. J., Davies, A. \& Lachmann, P. J. (2002). Streptococcal inhibitor of complement inhibits two additional components of the mucosal innate immune system: secretory leukocyte proteinase inhibitor and lysozyme. Infect Immun 70, 4908-4916.

Hancock, R. E. W. \& Chapple, D. S. (1999). Peptide antibiotics. Antimicrob Agents Chemother 43, 1317-1323.
Hirsch, J. G. (1960). Comparative bactericidal activities of blood serum and plasma serum. J Exp Med 112, 15-22.

Hoe, N. P., Vuopio-Varkila, J., Vaara, M. \& 7 other authors (2001). Distribution of streptococcal inhibitor of complement variants in pharyngitis and invasive isolates in an epidemic of serotype M1 group A Streptococcus infection. J Infect Dis 183, 633-639.

Hua, V. N., Williams, D. H. \& Schaeffer, A. J. (2005). Role of bacteria in chronic prostatitis/chronic pelvic pain syndrome. Curr Urol Rep $\mathbf{6}$, 300-306.

Ivanov, I. B. (2005). In vitro resistance to human platelet microbicidal protein among urethral staphylococcal and enterococcal isolates with its correlation with prostatitis. Indian J Med Microbiol 23, 253-255

Krijgsveld, J., Zaat, S. A. J., Meeldijk, J. \& 9 other authors (2000). Thrombocidins, microbicidal proteins from human platelets, are Cterminal deletion products of CXC chemokines. J Biol Chem 275, 20374-20381.

Kupferwasser, L. I., Skurray, R. A., Brown, M. H., Firth, N., Yeaman, M. R. \& Bayer, A. S. (1999). Plasmid-mediated resistance to thrombin-induced platelet microbicidal protein in staphylococci: role of the qacA locus. Antimicrob Agents Chemother 43, 2395-2399.

Kupferwasser, L. I., Yeaman, M. R., Shapiro, S. M., Nast, C. C. \& Bayer, A. S. (2002). In vitro susceptibility to thrombin-induced platelet microbicidal protein is associated with reduced disease progression and complication rates in experimental Staphylococcus aureus endocarditis: microbiological, histopathologic, and echocardiographic analyses. Circulation 105, 746-752.

Langley, R., Wines, B., Willoughby, N., Basu, I., Proft, T. \& Fraser, J. D. (2005). The staphylococcal superantigen-like protein 7 binds IgA and complement $\mathrm{C} 5$ and inhibits IgA-Fc $\alpha \mathrm{RI}$ and serum killing of bacteria. J Immunol 174, 2926-2933.

Lowentritt, J. E., Kawahara, K., Human, L. G., Hellstrom, W. J. G. \& Domingue, G. J. (1995). Bacterial infection in prostatodynia. J Urol 154, 1378-1381.

Schoor, R. A. (2002). Prostatitis and male infertility: evidence and links. Curr Urol Rep 3, 324-329.

Terai, A., Ishitoya, S., Mitsumori, K. \& Ogawa, O. (2000). Molecular epidemiological evidence for ascending urethral infection in acute bacterial prostatitis. J Urol 164, 1945-1947.

Wu, T., Yeaman, M. R. \& Bayer, A. S. (1994). In vitro resistance to platelet microbicidal protein correlates with endocarditis source among bacteremic staphylococcal and streptococcal isolates. Antimicrob Agents Chemother 38, 729-732.

Yeaman, M. R. (1997). The role of platelets in antimicrobial host defense. Clin Infect Dis 25, 951-968.

Yeaman, M. R., Puentes, S. M., Norman, D. C. \& Bayer, A. S. (1992). Partial characterization and staphylocidal activity of thrombininduced platelet microbicidal protein. Infect Immun 60, 1202-1209. 